\title{
CCR6 is required for ligand-induced CatSper activation in human sperm
}

\author{
Ruiying Diao ${ }^{1, *}$, Tao Wang ${ }^{2, *}$, Kin Lam Fok ${ }^{3, *}$, Xiaofeng Li ${ }^{3}$, Yechun Ruan ${ }^{3,4}$, Mei \\ Kuen Yu${ }^{3}$, Yimin Cheng ${ }^{2}$, Ying Chen ${ }^{2}$, Hao Chen ${ }^{1,3}$, Lisha Mou ${ }^{1}$, Xueyong Cai ${ }^{1}$, Yan \\ Wang $^{3}$, Zhiming $\mathrm{Cai}^{1}$, Xuhui Zeng ${ }^{2}$ and Hsiao Chang Chan ${ }^{3,5}$ \\ ${ }^{1}$ Shenzhen Key Laboratory of Genitourinary Tumor, Shenzhen Second People's Hospital, First Affiliated Hospital of Shenzhen \\ University, Shenzhen, China \\ ${ }^{2}$ Institute of Life Science and School of Life Science, Nanchang University, Nanchang, China \\ ${ }^{3}$ Epithelial Cell Biology Research Center, School of Biomedical Sciences, Faculty of Medicine, The Chinese University of Hong \\ Kong, Hong Kong SAR, China \\ ${ }^{4}$ Interdisciplinary Division of Biomedical Engineering, The Hong Kong Polytechnic University, Hong Kong SAR, China \\ ${ }^{5}$ Shenzhen Research Institute, The Chinese University of Hong Kong, Shenzhen, China \\ *These authors have contributed equally to this work \\ Correspondence to: Hsiao Chang Chan, email: hsiaocchan@cuhk.edu.hk
}

Xuhui Zeng, email: xuhuizeng@hotmail.com

Zhiming Cai, email: caizhiming2000@163.com

Key words: CCR6, CatSper, human $\beta$-defensin-1, progesterone, sperm

Received: May 26, $2017 \quad$ Accepted: July 13, $2017 \quad$ Published: September 05, 2017

Copyright: Diao et al. This is an open-access article distributed under the terms of the Creative Commons Attribution License 3.0 (CC BY 3.0), which permits unrestricted use, distribution, and reproduction in any medium, provided the original author and source are credited.

\section{ABSTRACT}

CatSper channel has been considered the principal sperm $\mathrm{Ca}^{2+}$ channel responsible for the cytosolic $\mathrm{Ca}^{2+}$ elevation required for various sperm functions necessary for fertilization [1-4]. However, the mechanism underlying the activation of CatSper channel by various physiological ligands remain incompletely understood. We have recently demonstrated the expression of C-C chemokine receptor 6 (CCR6) in sperm and $\mathrm{Ca}^{2+}$ influx upon binding of human $\beta$-defensin 1 (DEFB1) to CCR6, which is important for sperm motility [5]. In the present study, we have demonstrated that CCR6 receptor and CatSper channel are both required for the $\mathrm{Ca}^{2+}$ entry/current induced by physiological ligands DEFB1, chemokine (C-C motif) ligand 20 (CCL20) and progesterone in human sperm. CCR6 is co-localized and interacts with CatSper in human sperm. $\mathrm{Ca}^{2+}$ influx mediated by CCR6 and CatSper is required for essential sperm functions, including motility, hyperactivation and acrosome reaction, which are impaired in infertile sperm showing reduced levels of CCR6 and CatSper. The present finding suggests a critical role of CCR6 receptor in mediating ligand-induced, CatSperdependent $\mathrm{Ca}^{2+}$ influx required for various sperm functions and thus male fertility.

\section{INTRODUCTION}

CatSper channel is a sperm $\mathrm{Ca}^{2+}$ channel consisting of four pore-forming subunits CatSper1-4 and three auxiliary subunits CatSper $\beta, \gamma$ and $\delta[3,6-9]$. Spermatozoa from mice with knockout of individual CatSper subunits 1-4 have decreased motility and fail to undergo hyperactivation $[2,10,11]$. As a result, these spermatozoa are unable to fertilize the egg, leading to the sterile phenotype $[2,10,11]$. In human sperm, the CatSper channel has been shown to mediate the $\mathrm{Ca}^{2+}$ influx induced by progesterone $[12,13]$, which can be released from the outer layer of the egg, the cumulus cells, and activate sperm hyperactivation and acrosome reaction $[14,15]$. Recent studies further shown that orphan enzyme ABHD2 act as a steroid-selective, progesterone-dependent lipid hydrolase 
that depletes endocannabinoid 2-arachidonoylglycerol (2AG) to activate CatSper channel $[16,17]$. Apart from progesterone, another ligands odorants directly activate CatSper through cAMP-independent pathway [18]. These results suggest the polymodal nature of the CatSper channel in sensing various ligands involved in regulating sperm functions. However, the mechanism underlying the activation of CatSper channel by various ligands remain largely unknown.

CCR6 was first identified on lymphocytes and subsequently shown to be expressed by immature dendritic cells and memory $\mathrm{T}$ cells for adaptive immunity [19]. Three different ligands have been shown to bind to CCR6: macrophage inflammatory protein-3alpha (MIP3alpha; or CCL20), human $\beta$-defensins 1 and 2 (DEFB1 and DEFB2)[20]. Recent studies have shown that CCR6 is also expressed in sperm [5, 21] and we have also demonstrated that the binding of DEFB1 to CCR6 elicits $\mathrm{a} \mathrm{Ca}^{2+}$ elevation in human sperm required for their motility [5]. Although it was not clear what type of $\mathrm{Ca}^{2+}$ channel was involved in mediating the DEFB1-induced $\mathrm{Ca}^{2+}$ entry, this $\mathrm{Ca}^{2+}$ mobilization could be abolished by specific antibody against CCR6 [5]. Since CatSper is considered the principal $\mathrm{Ca}^{2+}$ channel in sperm, we suspected its involvement in mediating the DEFB1-induced, CCR6mediated $\mathrm{Ca}^{2+}$ mobilization. We undertook the present study to examine its importance in sperm functions and male fertility in human sperm from normal subjects and infertile patients.

\section{RESULTS}

\section{DEFB1-induced $\mathrm{Ca}^{2+}$ mobilization requires CatSper channel}

To test the potential involvement of CatSper channel in DEFB1-induced $\mathrm{Ca}^{2+}$ mobilization, we first examined the DEFB1-induced $\mathrm{Ca}^{2+}$ mobilization in the head region using a $\mathrm{Ca}^{2+}$ sensitive fluorescent probe since CatSper-mediated $\mathrm{Ca}^{2+}$ influx can trigger a $\mathrm{Ca}^{2+}$ propagation toward the sperm head [22]. Recombinant DEFB1 (rDEFB1; $800 \mathrm{ng} / \mathrm{ml}$ ) elicited a sustained elevation of intracellular $\mathrm{Ca}^{2+}$ level $\left(\left[\mathrm{Ca}^{2+}\right]_{\mathrm{i}}\right)$ in $\mathrm{Ca}^{2+}$-containing medium compared to $\mathrm{Ca}^{2+}$-free medium (Figure 1A-1B), suggesting that DEFB1 triggers $\mathrm{Ca}^{2+}$ influx. A neutralizing antibody against CCR6 receptor $(20 \mu \mathrm{g} / \mathrm{ml})$ [5], which targets amino acid position 151-231 that includes an extracellular motif, almost completely blocked the $\mathrm{Ca}^{2+}$ influx induced by rDEFB1 while control IgG did not have significant effect (Figure 1A-1B), indicating the requirement of CCR6 in mediating the $\mathrm{Ca}^{2+}$ response. Similarly, CatSper channel inhibitors, NNC 55-0396 or mibefradil [12, 13], used at $2 \mu \mathrm{M}$ and $40 \mu \mathrm{M}$, mimicked the effect of CCR6 antibody and resulted in nearly complete blockage of the $\left[\mathrm{Ca}^{2+}\right]_{\mathrm{i}}$ increase induced by rDEFB1 (Figure 1A-1B). These results suggest that the DEFB1-induced $\mathrm{Ca}^{2+}$ influx is dependent on both CCR6 and CatSper.
Next, we tested if CCL20, another CCR6 ligand found in follicular fluid and seminal plasma [21], could similarly lead to CatSper-mediated $\mathrm{Ca}^{2+}$ influx. Indeed, treatment of sperm with CCL20 (50 ng/ml) also triggered $\mathrm{Ca}^{2+}$ influx, which could be blocked by either CCR6 antibody or CatSper inhibitors (Figure 1C). Taken together, these results suggest that physiological ligands of CCR6, either DEFB1 or CCL20, can induce CatSperdependent $\mathrm{Ca}^{2+}$ influx in human sperm.

\section{CCR6 receptor ligands induce CatSper channel activity}

To examine the direct effect of DEFB1 and CCL20 on CatSper channel activity, we assessed their effect on CatSper current $\left(I_{\text {CatSper }}\right)$ by whole-cell patch clamp technique with access resistance ranged from 10-15 M 2 . A characteristic of CatSper channel is the absence of $I_{\text {CatSper }}$ when recording in the $2 \mathrm{mM} \mathrm{Ca}^{2+}$-containing extracellular normal physiological solution (HS) even under alkaline intracellular environment ( $\mathrm{pH}$ 7.2) [4]. However, when perfusing with the divalent-free solution (DVF), where $\mathrm{Ca}^{2+}$ was chelated by $5 \mathrm{mM}$ EGTA, a sizeable monovalent $I_{\text {CatSper }}$ can be recorded [12]. Thus, we investigated the effect of DEFB1 on CatSper under DVF condition. As shown in Figure 2A, rDEFB1 exerted a stimulating effect on CatSper at a concentration as low as $1 \mathrm{ng} / \mathrm{ml}$ and showed a half activation around $20 \mathrm{ng} / \mathrm{ml}$. The maximum concentration of rDEFB1 tested in this set of experiments $(500 \mathrm{ng} / \mathrm{ml})$ induced a $1.66 \pm 0.35$ fold increase in $I_{\text {CatSper }}$ at $+100 \mathrm{mV}$. To measure rDEFB1-induced $I_{\text {CatSper }}$ at physiological range of potentials, we analyzed the current amplitude at $-80 \mathrm{mV}$ and $+80 \mathrm{mV}$ respectively. Consistent with previous results, rDEFB1 induced sizable $I_{\text {CatSper }}$ which could be blocked by mibefradil $(30 \mu \mathrm{M})$ (Figure 2B-2C) or CCR6 antibody (Figure 2D-2E) at $-80 \mathrm{mV}$. On the contrary, rDEFB1 at $100 \mathrm{ng} / \mathrm{ml}$, which increased CatSper current substantially (Figure 2A), had no effect on potassium channel KSper (Supplementary Figure 1), suggesting that DEFB1 specifically activates CatSper. Similar to the results obtained from DEFB1 treatment, CCL20 also evoked $I_{\text {CatSper }}$, which was blunted by CCR6 antibody treatment (Figure 2F-2G), suggesting that binding of CCL20 to its receptor CCR6 also activates CatSper channel.

To confirm that the currents induced by DEFB1 and CCL20 were genuinely mediated by CatSper channel, we performed patch-clamp experiments on sperm samples donated by an infertile male who carries a $\mathrm{G}$ to $\mathrm{C}$ mutation of CatSper 2 in one allele and complete absence of CatSper2 in the other allele. The patient's spermatozoa were demonstrated to have no detectable CatSper current, as evidenced by a constant current amplitude upon switching extracellular solution from $2 \mathrm{mM} \mathrm{Ca}^{2+}$ containing HS to DVF (Figure 2H-2I). As expected, treating these CatSper-lacking sperm with either rDEFB1 
A

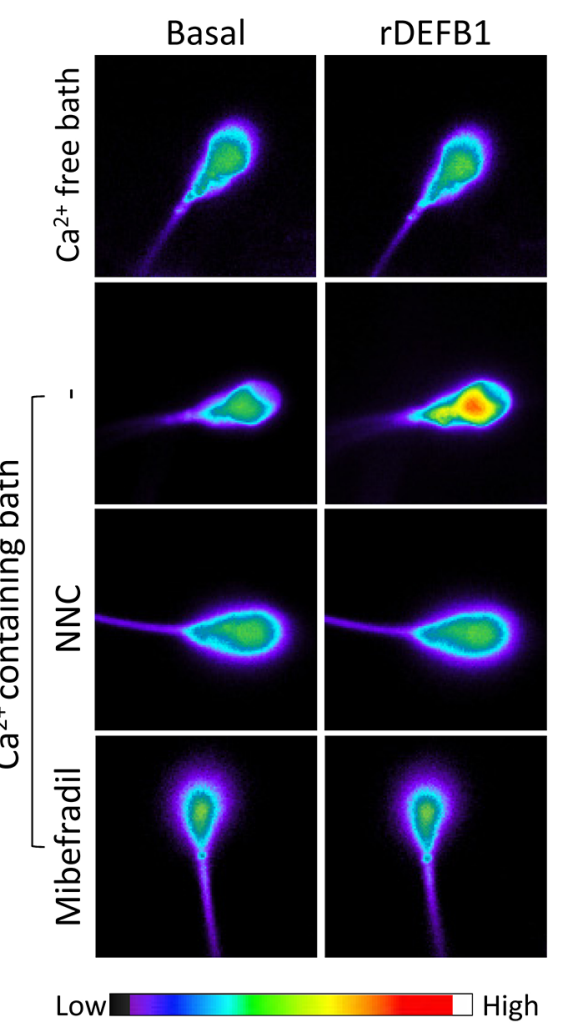

B
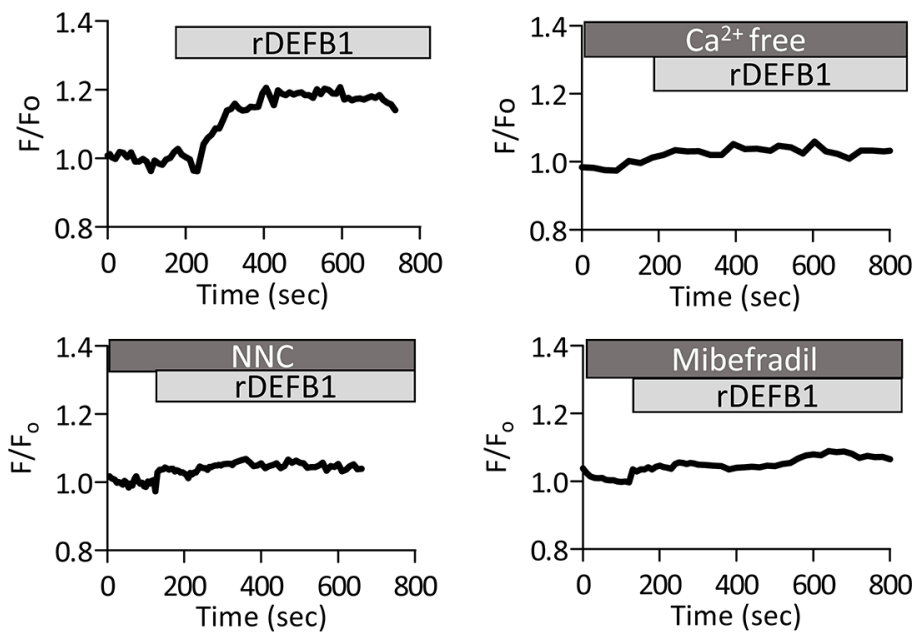

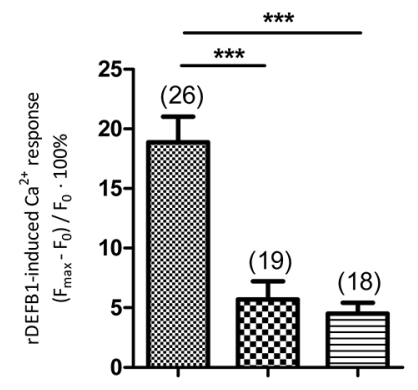

rHBD-1 peptide

Ex NNC + rHBD-1

Mibefradil + rBDH-1

C
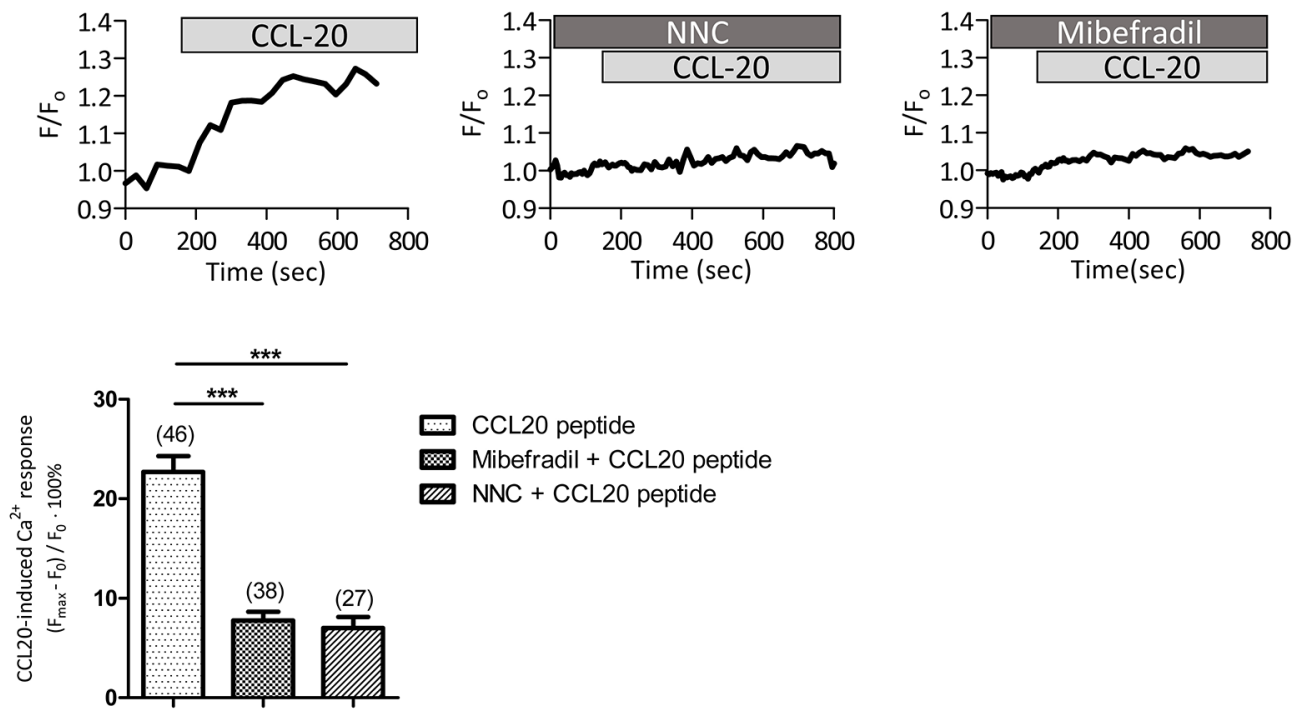

CCL20 peptide

Mibefradil + CCL20 peptide

m NNC + CCL20 peptide

Figure 1: DEFB1-induced $\mathrm{Ca}^{2+}$ influx in human sperm depends on both CCR6 receptor and CatSper channel. (A) Representative fluorescence images of human sperm loaded with Fluo-4, a Ca ${ }^{2+}$ sensitive dye, before (basal) and after the addition of rDEFB1 $(800 \mathrm{ng} / \mathrm{ml})$ into $\mathrm{Ca}^{2+}$-free or $\mathrm{Ca}^{2+}$-containing bath in the absence or presence of CatSper inhibitors, NNC55-0396 (NNC, $\left.2 \mu \mathrm{M}\right)$ or mibefradil $(40 \mu \mathrm{M})$, with color code bar shown below. (B) Representative time-course change in Fluo-4 intensity (F) normalized to the initial intensity $\left(\mathrm{F}_{0}\right)$ in the human sperm under different treatments (indicated by bars on the top). Bottom, statistic summary of the rDEFB1induced $\mathrm{Ca}^{2+}$ responses as indicated by the difference (in $\%$ of $\mathrm{F}_{0}$ ) between $\mathrm{F}_{0}$ and the maximal fluorescence intensity $\left(\mathrm{F}_{\max }\right)$ achieved after the addition of $\mathrm{rDEFB} 1$. Data are presented as mean $\pm \mathrm{SEM}$. Number of measured sperm is show in each column $(* * * \mathrm{p}<0.001$, One-way ANOVA). (C) Time-course change in Fluo-4 (F) normalized to $\mathrm{F}_{0}$ in human sperm in response to CCL20 $(50 \mathrm{ng} / \mathrm{ml})$ in the presence or absence of NNC $(2 \mu \mathrm{M})$ or mibefradil $(40 \mu \mathrm{M})$. Bottom panel, statistic summary of CCL20-induced $\mathrm{Ca}^{2+}$ responses (in $\left.\% \mathrm{~F}_{0}\right)$. Data are presented as mean \pm SEM. Number of measured sperm is show in each column (*** $p<0.001$, One-way ANOVA). 

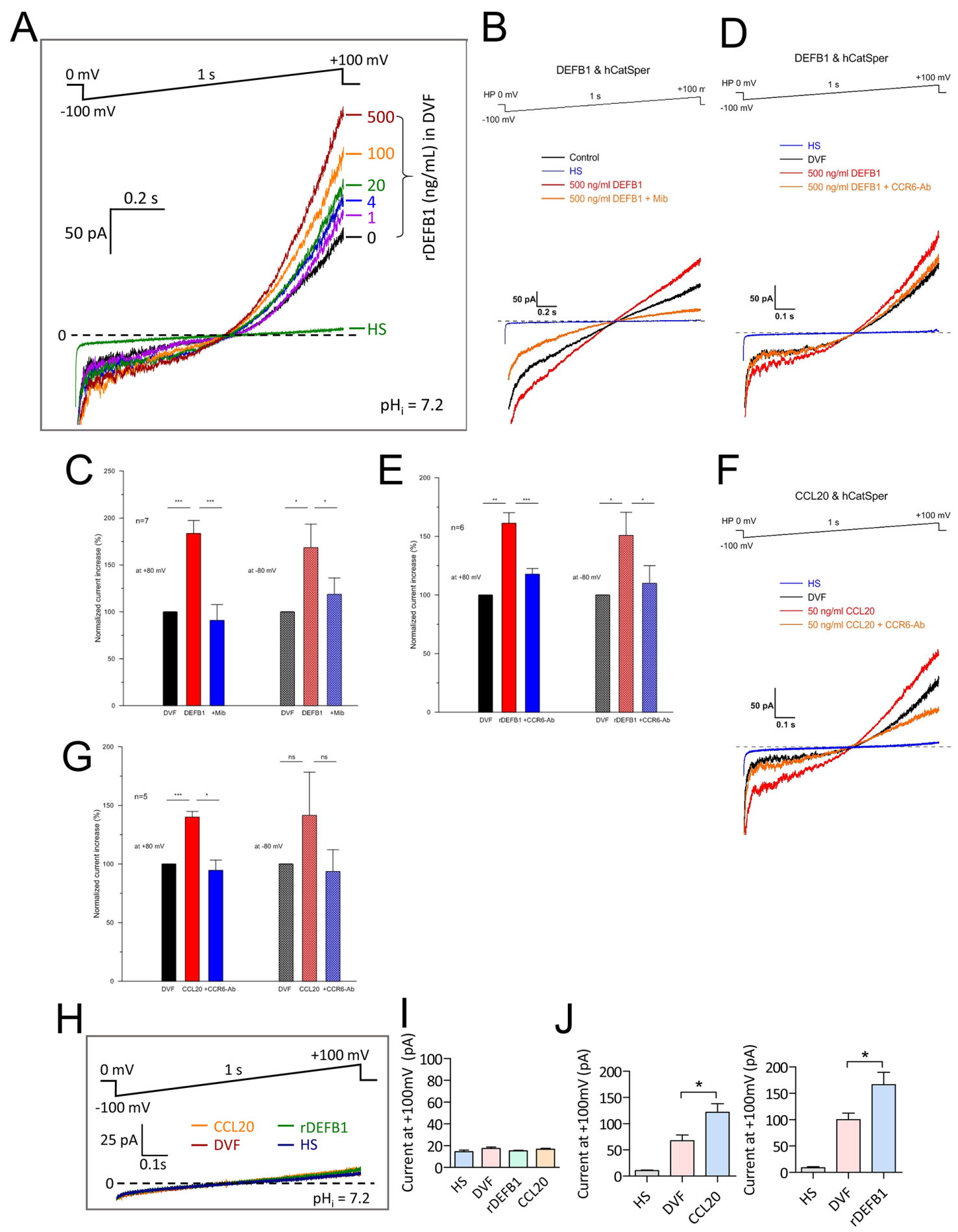

Figure 2: Activation of CatSper currents by CCR6 ligands in human sperm. (A-G) Representative patch-clamp recording (A, B \&D) of whole-cell currents in normal human sperm elicited from a holding voltage of $0 \mathrm{mV}$ by $1 \mathrm{~s}$ voltage ramp from -100 to +100 $\mathrm{mV}$ with pipette $\mathrm{pH}\left(\mathrm{pH}_{\mathrm{i}}\right)$ at 7.2. The sperm were bathed initially in HS (for divalent currents) and then DVF (for monovalent $I_{\text {CatSper }}$ currents) before subsequent addition of CCR6 ligands, rDEFB1 (1-500 ng/mL, A-E) or CCL20 (50 ng/ml, F-G) into the DVF bath. CatSper inhibitor mibefradil (40 $\mu \mathrm{M}, \mathrm{B})$ or CCR6 neutralizing antibody (CCR6-Ab, $20 \mu \mathrm{g} / \mathrm{ml}$ ) were added prior to addition of CCR6 ligands. The currents elicited at -80 and $+80 \mathrm{mV}$ were used for statistical comparisons between different conditions $(\mathrm{C}, \mathrm{E} \& \mathrm{G})$. Data are means $\pm \mathrm{SEM}$ normalized to the current value in DVF. $\mathrm{n}$ (number of measured sperm) $=7$ (B), 6 (C) and 5 (E \& G) $(* \mathrm{p}<0.05, * * \mathrm{p}<0.01, * * * \mathrm{p}<0.001$, One-way ANOVA). (H-J) Patch-clamp recording (H) and statistical summary (I \& J) of whole-cell currents elicited by voltage ramp (-100 to $+100 \mathrm{mV}$ from holding of $0 \mathrm{mV}, 1 \mathrm{~s})$ in HS or DVF with subsequent addition of CCL20 $(50 \mathrm{ng} / \mathrm{ml}) \mathrm{or} \mathrm{rDEFB} 1(500 \mathrm{ng} / \mathrm{ml})$ in sperm obtained from an infertile patient with mutation in CatSper2 gene (I) or from normal individuals (J). Data are means \pm SEM. $n \geq 4$ (I) and 6 (J) $(* \mathrm{p}<0.05$, One-way ANOVA) 
or CCL20 in DVF solution did not induce detectable current (Figure 2I) while the same treatment in normal sperm induced sizeable $I_{\text {CatSper }}$ (Figure 2J). Together, these results indicate that the two CCR6 ligands indeed activate CatSper current.

\section{CCR6 and CatSper form a receptor complex for different ligands}

The observation that the DEFB1/CCL20-induced $\mathrm{Ca}^{2+}$ influx or CatSper current could be blocked by either CCR6 antibody or CatSper inhibitors indicates that both CCR6 and CatSper are required for mediating the DEFB1/CCL20 action. This prompted us to speculate that CCR6 and CatSper might interact or at least locate in close proximity to regulate $\mathrm{Ca}^{2+}$ influx. To test this, we employed immunofluorescence staining to examine the localization CCR6 and CatSper1, a major pore-forming subunit of the CatSper channel [2, 3]. Consistent with previous report [5], CCR6 was localized to the midpiece and principal piece in human sperm (Figure 3A). In addition to the previously reported localization in the principal piece [2], CatSper1 was also localized to the mid-piece and co-localized with CCR6 (Figure 3A). CatSper1 immunofluorescent signal was absent in sperm stained with blocking peptide-pretreated antibody, indicating the staining was specific (Figure 3A). We further used proximity ligation assay (PLA) to examine the potential interaction between CCR6 and CatSper1 $[23,24]$. Consistent with the immunofluorescent staining results, PLA signals, which indicates the close proximity of CCR6 and CatSper1, were observed at the mid-piece and principal piece (Figure 3B).

The close proximity of CCR6 receptor and CatSper channel and their involvement in mediating $\mathrm{Ca}^{2+}$ influx induced by physiological ligands DEFB1 and CCL20 prompted us to further investigate their possible involvement in mediating the response elicited by one of the best-known physiological factors in the female tract, progesterone, which has been previously shown to activate the CatSper channel and lead to $\mathrm{Ca}^{2+}$ influx $[12,13]$. The $\mathrm{Ca}^{2+}$ imaging results showed that addition of $500 \mathrm{nM}$ or $10 \mu \mathrm{M}$ progesterone triggered an acute increase in $\left[\mathrm{Ca}^{2+}\right]_{\mathrm{i}}$, which could be inhibited by CatSper inhibitor, mibefradil $(40 \mu \mathrm{M})$ (Figure 4A). Of note, the magnitude of $\left[\mathrm{Ca}^{2+}\right]$ elevation induced by progesterone was significantly higher than that induced by DEFB1 or CCL20 (Figure 1). CCR6 neutralizing antibody $(20 \mu \mathrm{g} / \mathrm{ml})$ also inhibited the progesterone-induced $\mathrm{Ca}^{2+}$ elevation (Figure 4A). Blocking the CCR6 receptor and inhibiting CatSper simultaneously did not produce significant additive effect in inhibiting the $\left[\mathrm{Ca}^{2+}\right]_{\mathrm{i}}$ elevation (Figure 4A), indicating that both CCR6 and CatSper are likely to be involved in the same pathway. In the patch-clamp experiments, CCR6 antibody also inhibited progesterone-induced $I_{\text {CatSper }}$ but not basal CatSper current (Figure 4B), excluding possible non-specific effect of the CCR6 antibody on CatSper channel. Thus, these results suggest that the CCR6 is also required for the progesterone-induced CatSper activation.

\section{CCR6 and CatSper act-in-concert in maintaining sperm functions}

Finally, we examined the role of CCR6 and CatSper in sperm functions. In the first set of experiments, we examined the effects of CCR6 and CatSper on DEFB1induced sperm motility. Normally, during sperm transit through the epididymis, DEFB1, produced and released by the epididymal epithelial cells, binds to sperm and induces motility [5]. Adding rDEFB1 to normal human sperm could not induce significant increase in sperm motility, however, CCR6 antibody $(20 \mu \mathrm{g} / \mathrm{ml})$ or CatSper inhibitor mibefradil $(40 \mu \mathrm{M})$ could each significantly decreased the forward motility, with no significant additive effect observed when used in combination (Figure 5A), suggesting that both CCR6 and CatSper are required for sustaining normal sperm motility. We further examined DEFB1-induced motility in infertile spermatozoa from asthenozoospermia patients, who had lowered level of DEFB1 (Supplementary Figure 2), as reported previously [5]. Treatment of the patients' spermatozoa with rDEFB1 $(800 \mathrm{ng} / \mathrm{ml})$ restored the motility to above $50 \%$ (Figure 5A), and the rDEFB-rescued motility could be blunted by either CCR6 antibody or CatSper inhibitor with no significant additive effect observed when used in combination (Figure 5A). Similar results were obtained in normal and infertile sperm treated with CCL20 (Supplementary Figure 3). Together, these results suggested that CCR6 and CatSper act-in-concert in mediating DEFB1 and CCL20-induced $\mathrm{Ca}^{2+}$ influx required for sperm motility.

In human sperm, progesterone induces hyperactivation and acrosome reaction [14]. If the CCR6 and CatSper are both involved in mediating the effect of progesterone in these processes, we would expect the progesterone effect to be blunted by either CCR6 antibody or CatSper inhibitor. Indeed, the effects of progesterone on hyperactivated motility (Figure 5B) and the acrosome reaction (Figure 5C-5D) were blocked by either the CCR6 neutralizing antibody and/or CatSper inhibitor (Figure 5B5D). Taken together, these results suggest that similar to the DEFB1-induced sperm motility, both CCR6 and CatSper are also required for progesterone-induced hyperactivation and the acrosome reaction. This led us to speculate that spermatozoa obtained from asthenozoospermia patients with reduced levels of either CCR6 [5] or CatSper [25] (Supplementary Figure 2) should also exhibit defects in hyperactivation and acrosome reaction. To test this, we examined progesterone-induced hyperactivation and acrosome reaction in spermatozoa from the same cohort of asthenozoospermia patients, and the results showed that both the progesterone-induced hyperactivation and 

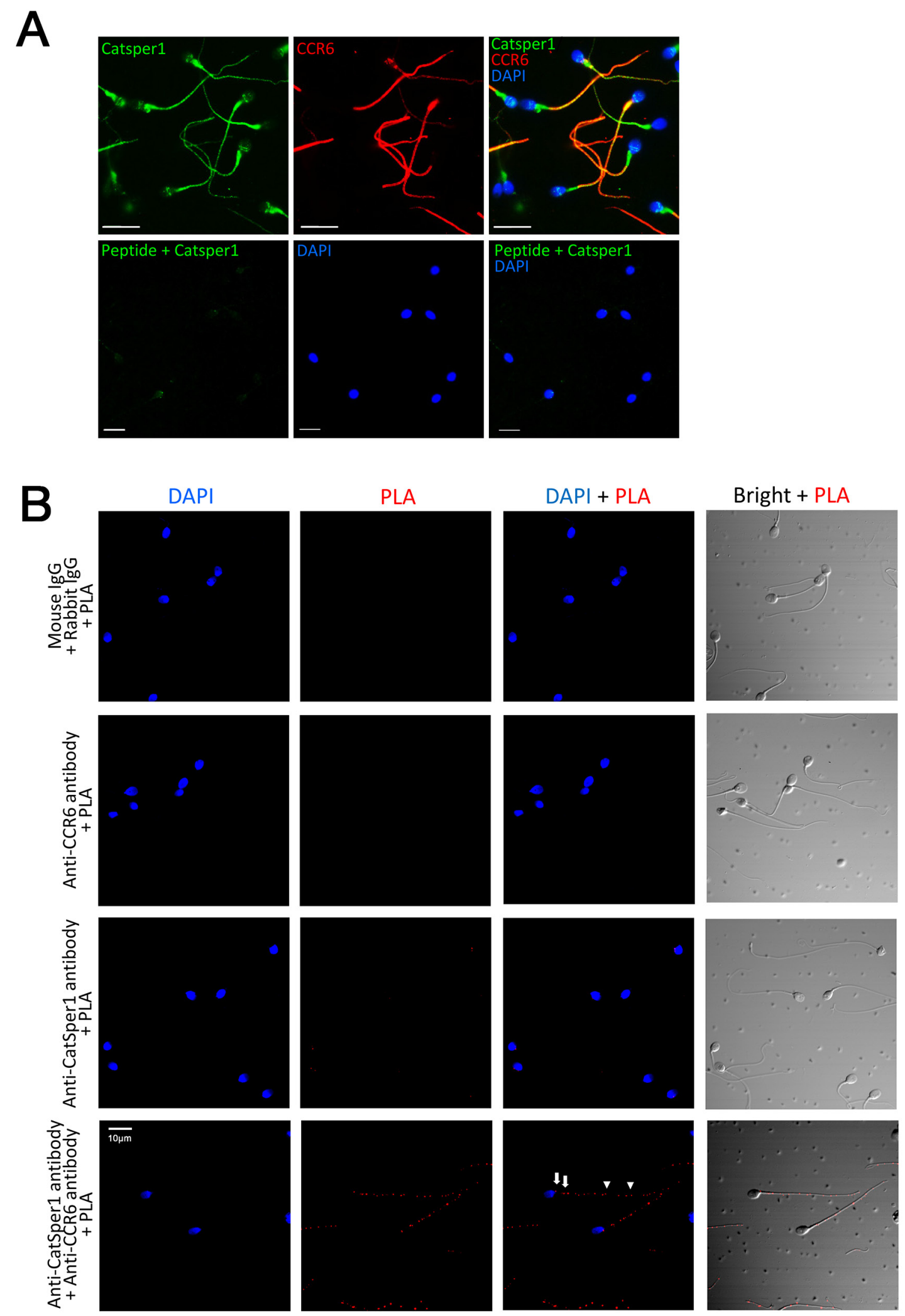

Figure 3: CCR6 interacts with CatSper1 in human sperm. (A) Representative fluorescence images showing the localization of CatSper1 (green) and CCR6 (red) in the principal and mid-piece of normal human sperm. Bottom panel, the antibody against CatSper1 was pre-absorbed with an antigen peptide before staining. Nuclei were counterstained with DAPI (blue). Bars $=10 \mu \mathrm{m}$. (B) Representative proximity ligation assay (PLA) images showing the close proximities of CatSper1 and CCR6 (bottom right) in the principal (arrow heads) and mid-piece (arrows) of normal human sperm. Sperm samples labelled with normal IgGs with PLA (top left), anti-CCR6 antibody with PLA (top right) or anti-CatSper1 antibody with PLA (bottom left) were used as control. Bars $=10 \mu \mathrm{m}$. 
acrosome reaction were significantly impaired in patients' spermatozoa compared to those obtained from normal men (Figure 5E-5F), confirming an important role of the CCR6 and CatSper in sperm functions.

\section{DISCUSSION}

The present study has identified a previously unexpected role of CCR6 receptor and CatSper channel in human sperm that act-in-concert in mediating ligand- induced $\mathrm{Ca}^{2+}$ responses required for various sperm functions. This finding provides a mechanism explaining the recently discovered role of DEFB1 in regulating sperm motility [5]. Our previous study has demonstrated that CCR6 is a receptor for DEFB1 in human sperm and that the binding of DEFB1 to CCR6 can result in cytosolic $\mathrm{Ca}^{2+}$ elevation and increase in motility. However, it was not clear how DEFB1 could trigger $\mathrm{Ca}^{2+}$ influx. The present study has provided strong evidence for the involvement of CatSper in a complex with CCR6 that mediates the CCR6
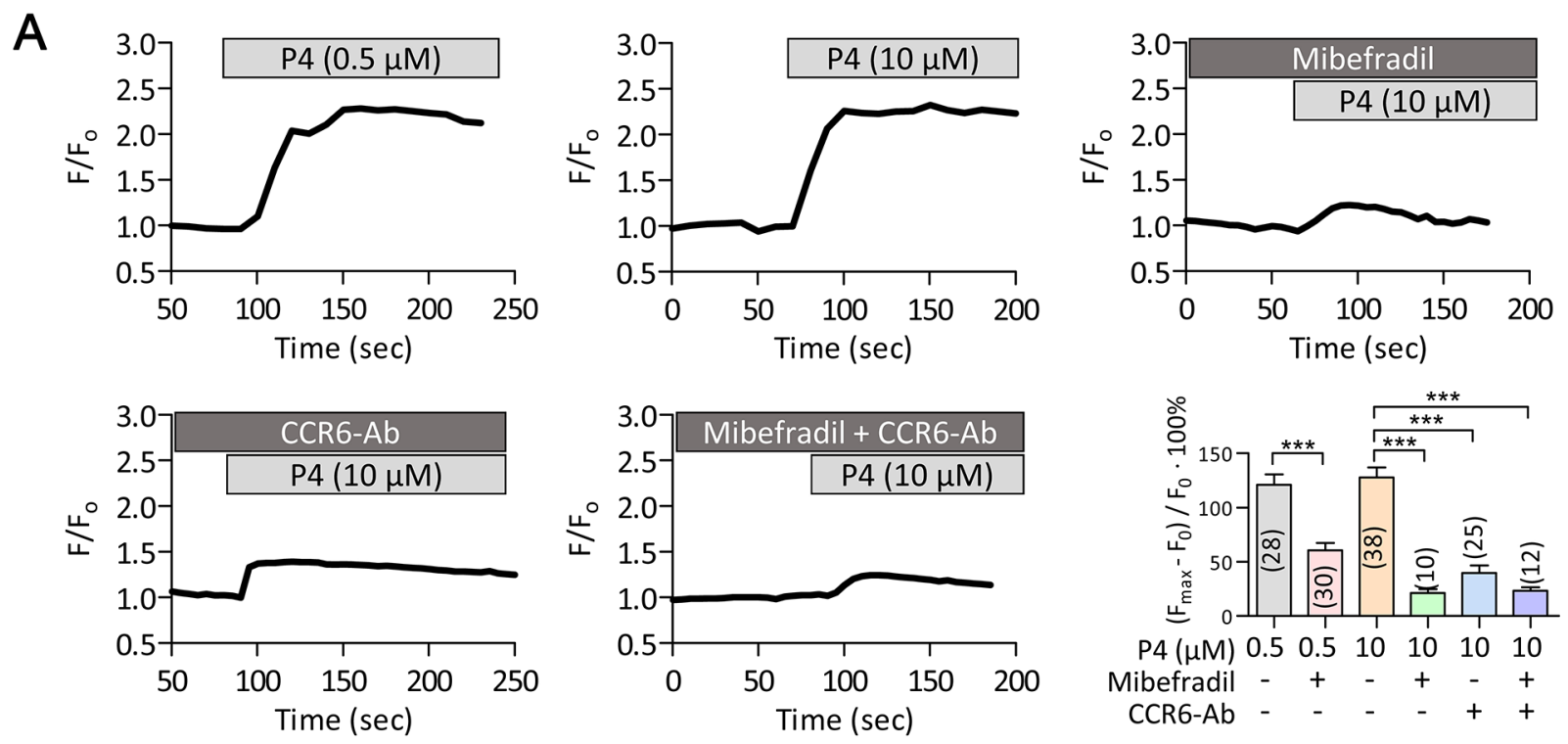

B

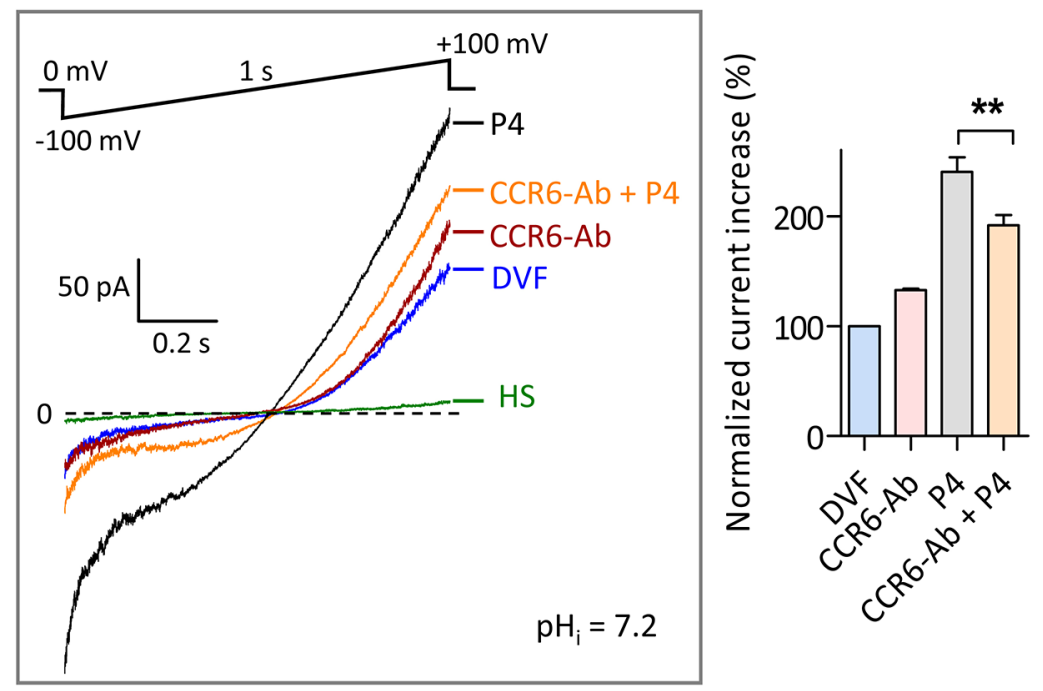

Figure 4: Involvement of CCR6 receptor in progesterone-induced $\mathrm{Ca}^{2+}$ influx in human sperm. (A) Time-course change in Fluo-4 (F) normalized to the initial intensity $\left(\mathrm{F}_{0}\right)$ in normal human sperm in response to progesterone $(\mathrm{P} 4,0.5-10 \mu \mathrm{M})$ in the presence or absence of mibefradil $(40 \mu \mathrm{M})$, CCR6-Ab $(20 \mu \mathrm{g} / \mathrm{ml})$ or both. Bottom right, statistic summary of P4-induced Ca ${ }^{2+}$ responses as indicated by the difference (in $\% \mathrm{~F}_{0}$ ) between $\mathrm{F}_{0}$ and the maximal florescence intensity $\left(\mathrm{F}_{\max }\right)$ after $\mathrm{P} 4$ addition. Data are presented as mean \pm SEM. Number of measured sperm is indicated in each column (***p<0.001, One-way ANOVA). (B) Patch-clamp recording of whole-cell currents elicited by voltage ramp (-100 to $+100 \mathrm{mV}$ from holding of $0 \mathrm{mV}, 1 \mathrm{~s})$ bathed in HS or DVF in the absence or presence of a CCR6 neutralizing antibody (CCR6-Ab, $20 \mu \mathrm{g} / \mathrm{ml})$ with subsequent addition of P4 $(500 \mathrm{nM})$. Pipette $\mathrm{pH}(\mathrm{pHi})=7.2$. Statistic summary is shown on the right panel. Data are presented as mean \pm SEM. $n \geq 7$ (** $p<0.01$, One-way ANOVA). 
A

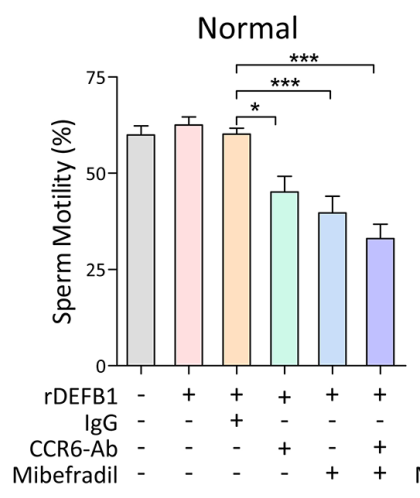

Astheno

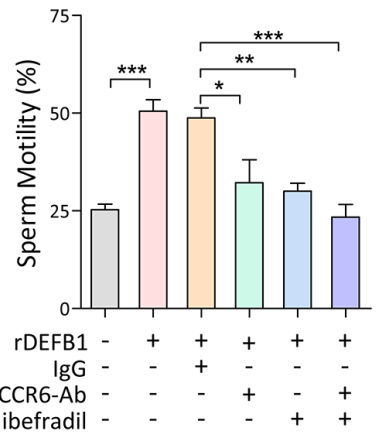

B

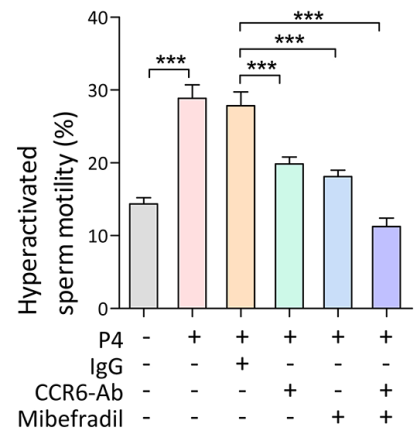

C
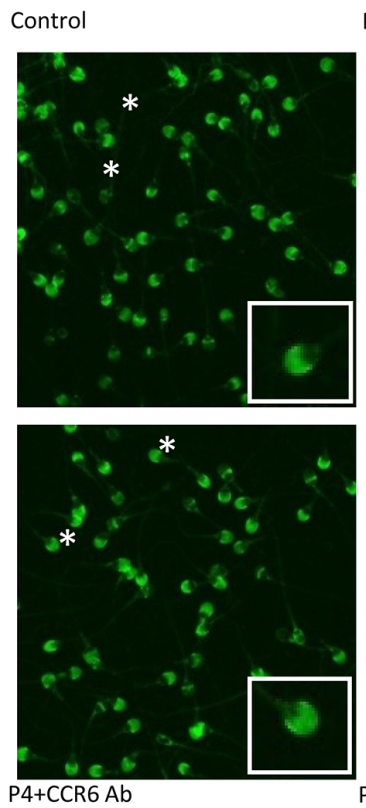

D

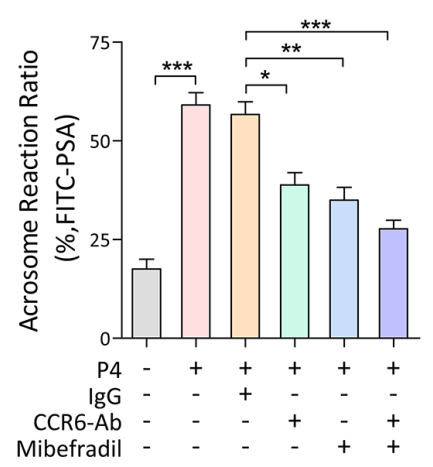

P4

P4+lgG
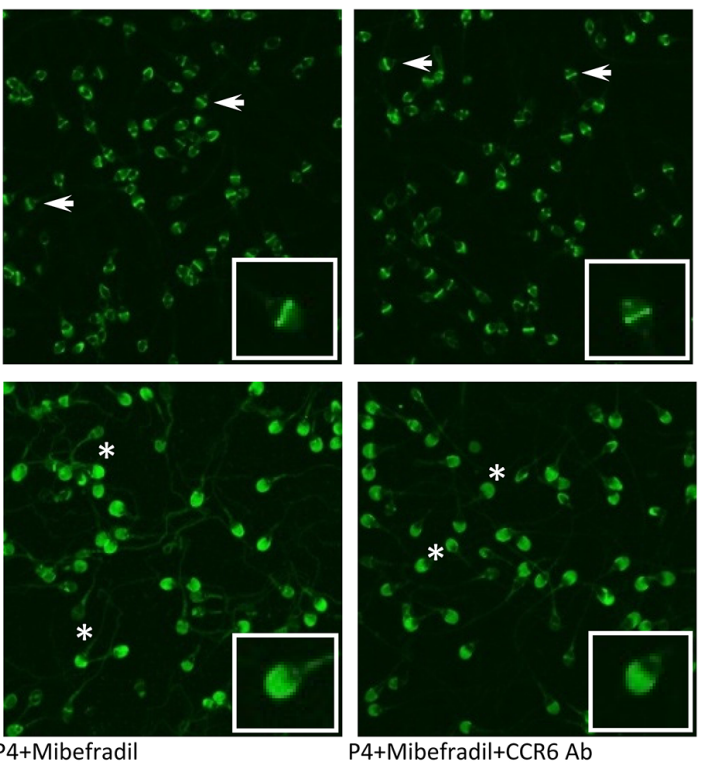

E

F

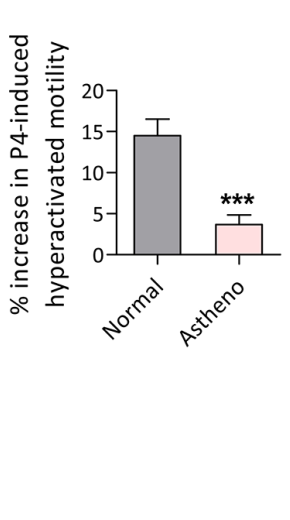

Figure 5: CCR6 and CatSper act in concert in mediating $\mathrm{Ca}^{2+}$-influx-dependent sperm functions. (A \& B) Computerassisted sperm analysis (CASA) measurement of DEFB1-induced motility (A, $\mathrm{n} \geq 11)$ and progesterone-induced hyperactivated motility (B, $\mathrm{n} \geq 16$ ) in sperm samples obtained from normal or asthenozoospermia patients in the presence or absence of the CCR6 neutralizing antibody (CCR6-Ab, $20 \mu \mathrm{g} / \mathrm{ml}$ ) and/or CatSper inhibitor (mibefradil, $40 \mu \mathrm{M})$. (C \& D) Representative fluorescence images of PSA staining (C) and quantification of acrosome reaction $(\mathrm{D}, \mathrm{n}=10)$ in indicated sperm samples treated with progesterone $(\mathrm{P} 4,10 \mu \mathrm{M})$ with or without $\mathrm{CCR} 6-\mathrm{Ab}$ $(20 \mu \mathrm{g} / \mathrm{ml})$ and/or mibefradil $(40 \mu \mathrm{M})$. Acrosome-intact and acrosome-reacted sperm were marked by asterisks and arrows respectively. Enlarged images are shown in insets. ( $\mathbf{E} \& \mathbf{F})$ Quantification of percentage increase in hyperactivated motility $(\mathrm{E}, \mathrm{n} \geq 11)$ and acrosome reaction $(\mathrm{F}, \mathrm{n}=10)$ induced by $\mathrm{P} 4(10 \mu \mathrm{M})$ in sperm obtained from normal and asthenozoospermia patients. Data are presented as mean \pm SEM. * $\mathrm{p}<0.05, * * \mathrm{p}<0.01, * * * \mathrm{p}<0.001$. One-way ANOVA (A, B and D), Student $t$ test (E and F). 
ligands (DEFB1 and CCL20)-induced $\mathrm{Ca}^{2+}$ influx or $I_{\text {Catsper }}$, as well as DEFB1/CCL20-induced sperm motility. More surprisingly, the presently identified a role of CCR6 in mediating, at least in part, the effect of progesterone on $\mathrm{Ca}^{2+}$ influx or $I_{\text {Cassper }}$, as well as progesterone-induced hyperactivation and acrosome reaction. The receptor for mediating the non-genomic effects of progesterone has long been under intense debate and recent studies have demonstrated that progesterone interacts with orphan enzyme ABHD2, which act as a progesterone receptor in sperm. $[16,17]$. Our findings suggest either that CCR6 acts as a co-factor in the progesterone-ABHD2 complex or that CCR6 mediates the progesterone-induced CatSper activation through an alternative pathway. Further study is required to test these possibilities. Nonetheless, we show that CCR6 is required for CatSper1-dependent $\mathrm{Ca}^{2+}$ influx induced by different ligands, including progesterone, in addition to DEFB1 and CCL20, and perhaps more. This in-concert role of CCR6 and CatSper appears to be multifunctional and responsible for the various ligandinduced $\mathrm{Ca}^{2+}$ responses required for sperm motility, hyperactivation and the acrosome reaction.

It has been shown that the motility of epididymal sperm increase progressively in vitro from the caput (head) towards the cauda (tail) region. However, in vivo, the sperm become quiescence for storage in the cauda possibly through a controlling/repressing mechanism [26]. Since DEFB1 is also expressed in the epididymis, if the binding of DEFB1 to CCR6 receptor activates the CatSper channel required for motility, this pathway may be subjected to similar controlling mechanism to facilitate the storage of sperm. In this scenario, the CCR6 - CatSper complex may
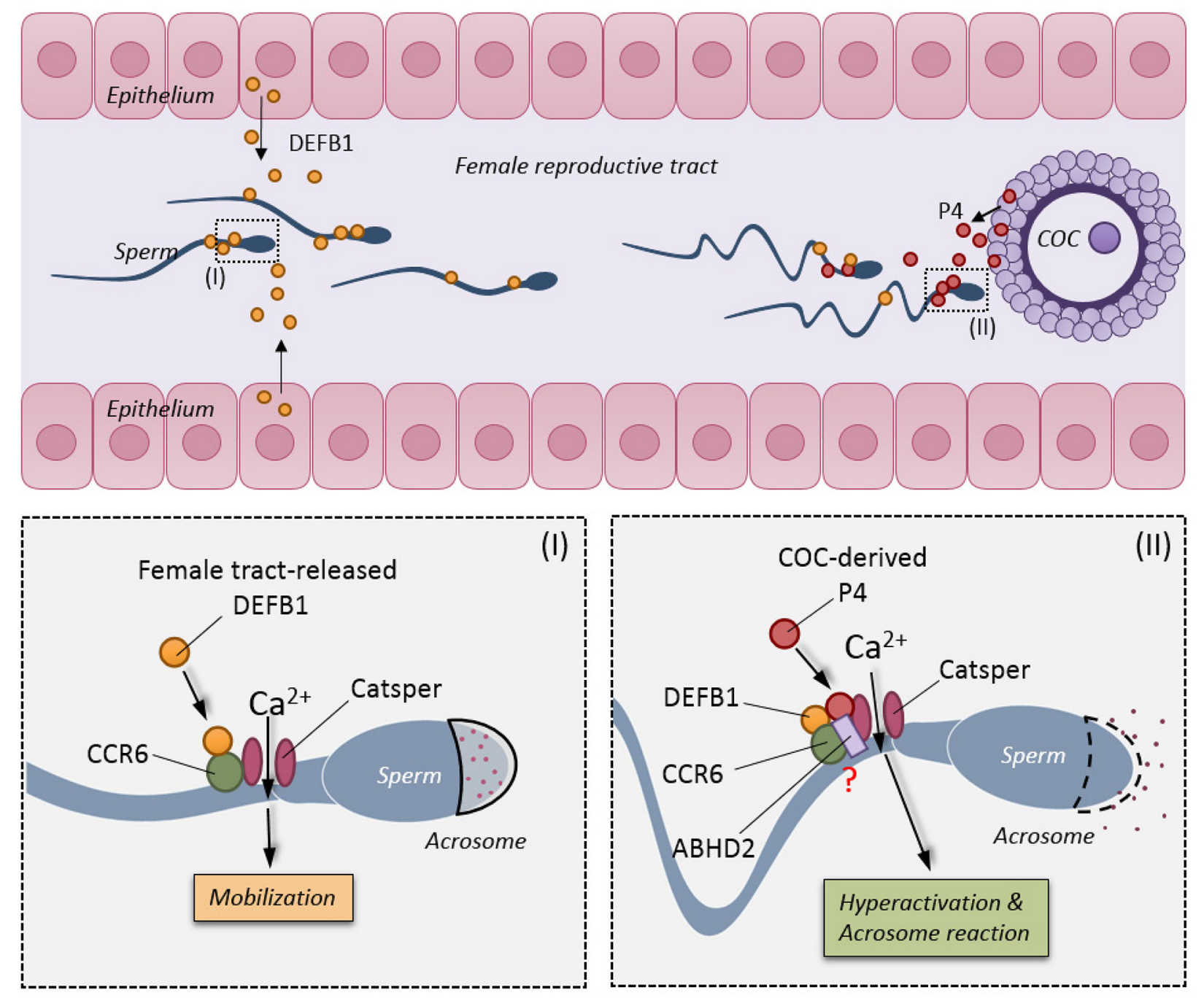

Figure 6: Schematic diagram showing the physiological roles of CCR6 receptor and CatSper channel in sperm. In the female reproductive tract, DEFB1 secreted from the uterine epithelium binds to CCR6 receptor and elicits a CatSper-dependent $\mathrm{Ca}^{2+}$ influx required for maintaining motility (bottom left). When sperm approach the fertilization site, progesterone secreted from the cumulusoocyte-complex binds to the CCR6/CatSper complex and triggers an acute and stronger CatSper-dependent $\mathrm{Ca}^{2+}$ influx that is essential for hyperactivation and acrosome reaction (bottom right). 
be the target for the control of sperm motility during the storage period. After the deposit of sperm into the female reproductive tract, the absence of controlling mechanism allows the sperm to regain motility upon the binding of female tract-derived DEFB1 and other CCR6 ligand that activate the CatSper channel.

CCR6 is a G-protein coupled receptor that triggers GTP-dependent intracellular signaling upon binding to its ligand [27]. Interestingly, the $I_{\text {Catsper }}$ induced by binding of DEFB1/CCL20 and possibly progesterone to CCR6 receptors do not require additional GTP in the pipette solution, suggesting either that the endogenous GTP is sufficient for the activation of CatSper channel or that CCR6 activates CatSper through a GTP-independent mechanisms [28]. Since CCR6 and CatSper co-localized to the same region on sperm, we propose that the binding of ligands to CCR6 receptor triggers conformational change that directly activates CatSper channel. This notion is supported by the results that blocking CCR6 receptors inhibits the CatSper-dependent $\mathrm{Ca}^{2+}$ influx induced by progesterone where intracellular signaling is very unlikely to be involved due to the rapid induction time $[12,13]$.

In the female reproductive tract, it has been reported that DEFB1 is secreted by the uterine epithelium and progesterone from the cumulus-oocyte complex $[14,15$, 29]. The presently demonstrated ability of these spatially differentially expressed/released physiological factors to activate CCR6 receptor and CatSper channel in human sperm suggests a sequential induction mechanism for a series of events leading to fertilization (Figure 6). For example, DEFB1, which is expressed in the female reproductive tract [30], sustains motility and helps sperm travel through the uterus, and then, when sperm are approaching the oviduct, progesterone released from the egg complex induces hyperactivation and the acrosome reaction that allow the sperm to fertilize the egg. Of note, progesterone induces a much more rapid and stronger $\mathrm{Ca}^{2+}$ response compared to that induced by DEFB1 and CCL20. It appears that while the CCR6 and CatSper can be activated by different ligands, the gating of CatSper or the magnitude of the $\mathrm{Ca}^{2+}$ response may depend on the type of ligands that sperm encounter. It is plausible that the CCR6 receptor may undergo ligand-dependent conformational changes, which may result in differential CatSper channel gating. Further work is required to test this possibility. The differential $\mathrm{Ca}^{2+}$ responses, both in the kinetics and magnitude, induced by different ligands, as currently demonstrated for DEFB1, CCL20 and progesterone, may explain how the CCR6 and CatSper are able to regulate different sperm functions essential for fertilization.

The importance of the CCR6 receptor and CatSper channel can be highlighted by the observed reduction in the expression levels of either CCR6 [5] or CatSper [25] or both in sperm from the infertile patients recruited in the current study, indicating that defects in any component of this receptor-channel module with various sperm malfunctions may contribute to different forms of male infertility. Notably, all sperm samples from the infertile patients cohort recruited in this study express lowered level, but not complete absence of CCR6 and CatSper1. Thus, it is plausible that the rDEFB1 fully activates the remaining receptor-channel module in restoring motility in patient's sperm. Despite the important roles of CCR6/ CatSper receptor-channel module in human sperm functions, CCR6 KO mice have been shown to be fertile [31]. It should be noted that fertilization appears to be quite distinct between mice and human [1]. In fact, the effect of progesterone in activating CatSper channel was only observed in human sperm but not mouse sperm [12]. Further, while we observed an essential role of DEFB1 in regulating the motility of human sperm and defending male fertility in humans [5], DEFB1 KO mice are fertile [32]. Thus, it is likely that the presently observed effects of these physiological ligands on CCR6 and CatSper are specific for human sperm.

In summary, the present study has revealed pivotal role of CCR6 receptor and CatSper channel in human sperm serving as a receptor-channel module for various physiological factors, including defensins and progesterone, that regulate a spectrum of sperm functions required for fertilization. The present study provides the evidence that CatSper channel activity can be modulated by different ligands through its proximal receptor CCR6. The presently demonstrated critical role of the CCR6 and CatSper in mediating ligand-induced $\mathrm{Ca}^{2+}$ influxes required for various sperm functions suggests that CCR6 and CatSper could be markers for diagnosis of male infertility and a potential target for fertility control.

\section{MATERIALS AND METHODS}

\section{Reagents}

Rabbit IgG (sc-2027), rabbit anti-human CatSper 1 (H300) (sc-33153), rabbit anti-CatSper 1 (Santa Cruz, sc-33153), rabbit anti-human CCR 6 (H-81) (sc-5623), goat anti-human CCR-6 (N-19) (sc-9695), mouse antihuman CCR6 (R\&D MAB195), and rabbit anti-human DEFB1 (FL-68) (sc-20797) antibodies were purchased from Santa Cruz Biotechnology (Santa Cruz, CA). Recombinant human active DEFB1 (ab50048) was purchased from Abcam (Cambridge, MA). CCL20 (360-MP-025/CF) was purchased from R \& D Systems. Quinn's human tubal fluid (HTF) (ART-1020) media was purchased from SAGE Media. Mouse monoclonal anti$\beta$-actin (1:5000, A1978), CatSper1 ion channel activator Progesterone (P8783), CatSper1 ion channel inhibitor Mibefradil (M5441) and NNC 55-0396 hydrate (N0287) were purchased from Sigma-Aldrich Co (St Louis, MO). Discontinuous density gradient Percoll (17-089101) was purchased from GE Healthcare Life Sciences (Pittsburg, PA). 


\section{Clinical samples}

The use of human specimens for this project was approved by the Regional Committee for Medical Research Ethics and the Human Ethics Committee of Shenzhen Second People's Hospital, and written consent was obtained from each subject.

Semen was obtained from healthy donors or infertile patients at Shenzhen Second People's Hospital according to World Health Organization Criteria [33] or at Human Sperm Bank in Jiangxi province and Maternal and Child Care Service Centre in Jiangxi province on the premise of voluntary. Subjects with a family history of endocrine or anatomical disorders were excluded from the study. Semen collection was done by masturbation after 3-5 day-sexual abstinence.

After complete liquefaction at $37^{\circ} \mathrm{C}$ for 30 minutes, parameters including semen volume, sperm concentration, sperm motility, sperm viability and sperm morphology were analyzed by a computer assisted semen analysis (CASA) system under $200 \times$ magnification. Normal controls were selected according to the following criteria: spontaneous pregnancy achieved within less than one year of pregnancy expectation and with the last pregnancy less than one year prior to study; total sperm motility (Progressive motility + Non-progressive motility, $\mathrm{PR}+\mathrm{NP}) \geq 40 \%\left(38-42 \%, 5^{\text {th }}\right.$ centile, $\left.95 \% \mathrm{Cl}\right)$, and sperm progressive motility (PR) $\geq 32 \%\left(31-34 \%, 5^{\text {th }}\right.$ centile, $95 \%$ $\mathrm{Cl}$ ). Subjects with sperm progressive motility (PR) $<32 \%$ were regarded as asthenozoospermia.

For the CatSper-lacking sperm sample, the number of sperm was $35.02 \times 10^{6} \mathrm{cells} / \mathrm{ml}$, of which $80.21 \%$ were motile. The percentage of PR (sperm with progressive and rapid motility) and NP (sperm with non-progressive motility) were respectively $52.78 \%$ and $19.79 \%$. Average path velocity (VAP) was $15.32 \mu \mathrm{m} / \mathrm{s}$. Curvilinear velocity (VCL) was $10.76 \mu \mathrm{m} / \mathrm{s}$. Straight line velocity (VSL) was $20.47 \mu \mathrm{m} / \mathrm{s}$. Amplitude of lateral head displacement (ALH) was $0.55 \mu \mathrm{m}$. And linearity of progression (LIN) was $52.55 \%$.

\section{Sperm motility assay by CASA}

After Percoll density gradient centrifugation, human sperm samples from normal and infertile patients were washed and adjusted to $1 \times 10^{6}$ cells $/ \mathrm{ml}$ using the Neubauer cell chamber in HTF (3\% BSA). The samples were incubated with either rDEFB1 $(800 \mathrm{ng} / \mathrm{ml})$, CCL20 $(50 \mathrm{ng} / \mathrm{ml})$ or progesterone $(10 \mu \mathrm{M})$ for one hour at $37^{\circ} \mathrm{C}$ under $5 \% \mathrm{CO}_{2}$ with or without anti-CCR 6 antibody (20 $\mu \mathrm{g} / \mathrm{ml}$ ) and/or CatSper1 inhibitor (Mibefradil, $40 \mu \mathrm{M}$ ) for further $15 \mathrm{~min}$ at $37^{\circ} \mathrm{C} .15 \%$ glycerol in PBS and normal rabbit IgG were included as vehicle controls.

For CASA analysis, $4 \mu \mathrm{l}$ of sperm suspension at a concentration of $1 \times 10^{6}$ cells $/ \mathrm{mL}$ was placed in a Counting Chamber $\left(0.01 \mathrm{~mm}_{2}, 10 \mu \mathrm{m}\right.$ deep$)$ and assessed for motility characteristics at $37^{\circ} \mathrm{C}$. For each sample, 10 randomly-selected fields containing more than 400 motile tracks were examined at $60 \mathrm{~Hz}$. Average values for sperm motion parameters including curvilinear velocity (VCL), straight-line velocity (VSL), average path velocity (VAP), amplitude of lateral head displacement (ALH), linearity $(\mathrm{LIN}=\mathrm{VSL} / \mathrm{VCL})$, and straightness $(\mathrm{STR}=\mathrm{VSL} / \mathrm{VAP})$ were recorded. Rapid or slow motile sperm cells were classified according to the CASA standard cutoff values for VAP and VSL. Slow cells were defined as cells with either of the following attributes: VAP $<20 \mu \mathrm{m} / \mathrm{s}$ or VSL $<30 \mu \mathrm{m} / \mathrm{s}$. Spermatozoa were designated as hyperactive if they had a VCL $\geq 150 \mu \mathrm{m} / \mathrm{s}$, ALH $\geq 7.0 \mu \mathrm{m} / \mathrm{s}$ and $\mathrm{LIN} \leq 50 \%$ [34]. The parameters of sperm movement assessed were graded a (the average velocity $\mathrm{R} 25 \mathrm{~mm} / \mathrm{s}$ ) and $\mathrm{b}$ (the average velocity between 15 and $25 \mathrm{~mm} / \mathrm{s}$ ). Forward motility was defined by percentage of sperm showing grade $a+b$ motility pattern.

\section{Immunofluorescence staining and confocal microscopy}

Sperm slides were incubated with both rabbit antiCatSper1 Ab (1:100 dilution, sc-33153) and goat antiCCR6 Ab (1:100 dilution, sc-9695) overnight at $4^{\circ} \mathrm{C}$. After washed three times, slides were incubated with Alexa 594-conjugated donkey-anti-rabbit and Alexa 488-conjugated donkey-anti-goat secondary antibodies for $1 \mathrm{~h}$ at room temperature. Slides were counterstained with Hoechst $33258(1 \mu \mathrm{g} / \mathrm{ml}$, Invitrogen, Camarillo CA) and mounted with Prolong $\AA$ Gold Antifade Reagent (Invitrogen, Camarillo CA, USA). Primary antibodies pre-incubated with neutralizing peptides were used as negative controls. The slides were then stored in a dark box before visualization. At least 200 sperm were captured randomly under a confocal microscope (Zeiss, Germany) for statistical analysis using Image-Pro Plus 5.1 software.

\section{Proximity ligation assay (PLA)}

Washed human spermatozoa were fixed in $4 \%$ formaldehyde for $15 \mathrm{~min}$ at $4^{\circ} \mathrm{C}$ and smeared onto slides. Proximity ligation assays were performed using the Duolink in situ PLA kit (Sigma). Slides were washed in PBS, and permeabilized with $0.1 \%$ Triton $\mathrm{X}-100$ in PBS for $5 \mathrm{~min}$. The slides were incubated in blocking solution for $1 \mathrm{hr}$ at room temperature, followed by an overnight incubation with anti-CCR6 (R\&D MAB195) (1:50) antibody in conjunction with anti-CatSper (Santa Cruz, sc-33153) (1:25) antibodies. After two washes with PBS, slides were incubated with two oligonucleotidelinked secondary antibodies (PLA probes) for $2 \mathrm{hr}$ at 37 ${ }^{\circ} \mathrm{C}$. Subsequent hybridization and ligation were carried out for $1 \mathrm{hr}$ and the amplification was carried out at 37 ${ }^{\circ} \mathrm{C}$ for $2 \mathrm{hr}$. Finally, slides were mounted with Duolin in Situ Mounting Medium with DAPI for 15 mins. Signals 
were captured using Olympus Fluoview FV1200 confocal microscope.

\section{Induced acrosome reaction assay (PSA-FITC)}

Human sperm samples from normal and infertile patients were adjusted to $1 \times 10^{6}$ cells $/ \mathrm{mL}$ using the Neubauer cell chamber in HTF (3\% BSA), then incubated for 3 hours at $37^{\circ} \mathrm{C}$ under $5 \% \mathrm{CO}_{2}$ in air to induce capacitation. Progesterone $(10 \mu \mathrm{M})$ was added with or without anti-CCR 6 antibody $(20 \mu \mathrm{g} / \mathrm{ml})$ and/or CatSper inhibitor (Mibefradil, $40 \mu \mathrm{M}$ )) for further $15 \mathrm{~min}$ at $37^{\circ} \mathrm{C}$. After fixed in ethanol, spermatozoa smear was dried in air and stained using PSA-FITC. About 400 spermatozoa were captured under X 400 magnification with oil immersion at 450-490 $\mathrm{nm}$ excitation.

\section{Intracellular $\mathrm{Ca}^{2+}$ measurement}

Spermatozoa were incubated with either rDEFB1 (800 ng/ml), CCL20 (50 ng/ml) or progesterone $(10 \mu \mathrm{M})$, respectively, with or without anti-CCR 6 antibody (20 $\mu \mathrm{g} / \mathrm{ml}$ ) and/or CatSper1 inhibitor (Miberfiral, $40 \mu \mathrm{M}$ ) at $37^{\circ} \mathrm{C}$ for $1 \mathrm{hr}$. Sperm were loaded with $5 \mathrm{uM}$ fluo-4, 1.5 uM Pluornic F-127 in modified sperm washing medium (97.8 mM NaCl, $4.69 \mathrm{mM} \mathrm{KCl}, 0.2 \mathrm{mM} \mathrm{MgSO}$, 0.37 $\mathrm{mM} \mathrm{KH} \mathrm{PO}_{4}, 2.04 \mathrm{mM} \mathrm{CaCl}_{2}, 4 \mathrm{mM} \mathrm{NaHCO}, 21 \mathrm{mM}$ HEPES, $2.78 \mathrm{mM}$ Glucose, $0.33 \mathrm{mM}$ Na pyruvate, 21.4 $\mathrm{mM} \mathrm{Na}$ lactate and $5 \mathrm{mg} / \mathrm{ml} \mathrm{BSA}$ ) in the dark at $32^{\circ} \mathrm{C}$ for $30 \mathrm{~min}$. After loading, sperm were washed with fresh modified sperm washing medium. 15\% glycerol in PBS and normal rabbit IgG were included as vehicle controls.

To start the experiment, sperm suspensions were deposited on the coverslip precoated with poly-L-lysine $(0.01 \% \mathrm{w} / \mathrm{v})$ for 2 minutes. Unattached sperm were removed by gently washing and the chamber was filled with modified washing medium. Measurement was made on an epifluorescence microscope (Nikon Eclipse Ti, Japan) with a $60 \mathrm{X}$ oil objective lens (1.40 NA) (Nikon, Japan) and a CCD camera (Spot Xplorer, USA) controlled by the software MetaFluor (Universal Imaging). Light was provided by the Xenon lamp (Hamamatsu, Japan). Excitation at $488 \mathrm{~nm}$ was used and emission was collected at $510 \mathrm{~nm}$. Changes in intracellular calcium level were calculated by percentage change of peak fluorescent intensity after treatment $\left(\mathrm{F}_{\max }\right)$ basal fluorescent intensity $\left(\mathrm{F}_{0}\right) / \mathrm{F}_{0}$.

\section{Whole-cell Patch-clamping recording}

After liquefaction for $1 \mathrm{hr}, 0.5 \mathrm{ml}$ standard bath solution (310 mOsm-HS) containing (in mM): $135 \mathrm{NaCl}$, $5 \mathrm{KCl}, 1 \mathrm{MgSO}_{4}, 2 \mathrm{CaCl}_{2}, 5$ glucose, $1 \mathrm{Na}$ pyruvate, 10 lactic acid, 20 HEPES (pH 7.4) was added to $1 \mathrm{ml} \mathrm{semen.}$ The resulting suspension was centrifuged at $500 \mathrm{~g}$ for 6 min. Pellet was washed with fresh $1.5 \mathrm{ml} \mathrm{HS}$ solution and centrifuged again. Spermatozoa were then resuspended in $1 \mathrm{ml} \mathrm{HS}$ and used for electrophysiological recordings.
All gigaohm seals $(>10 \mathrm{G} \Omega$ ) between the patch pipette and human uncapacitated spermatozoa were formed at the cytoplasmic droplet in standard bath solution (HS) containing (in $\mathrm{mM}$ ): $135 \mathrm{NaCl}, 5 \mathrm{KCl}, 1 \mathrm{MgSO}_{4}$, $2 \mathrm{CaCl}_{2}, 5$ glucose, $1 \mathrm{Na}$ pyruvate, 10 lactic acid, 20 HEPES adjust to $\mathrm{pH} 7.4$ with $\mathrm{NaOH}, 310 \mathrm{mOsm} / \mathrm{L}$. HS solution was also used to record baseline current while measuring monovalent CatSper currents $(\mathrm{Ca} 2+$ in $\mathrm{HS}$ solution inhibits monovalent CatSper currents and causes $\mathrm{Ca} 2+$-dependent inactivation of CatSper channels). Monovalent currents were recorded by perfusing with a sodium-based divalent-free solution (DVF) containing (in $\mathrm{mM}$ ): $150 \mathrm{NaCl}, 20 \mathrm{HEPES}$, and 5 EGTA adjusted to $\mathrm{pH} 7.4$ with $\mathrm{NaOH}$, perfusion time usually was more than 45 s. Pipettes (15-20 M $\Omega$ ) for whole-cell patch-clamp recordings of CatSper currents were filled with 135 CsMes, 10 HEPES, 10 EGTA, $5 \mathrm{CsCl}$ adjusted to $\mathrm{pH} 7.2$ with $\mathrm{CsOH}$. Some KSper recordings were performed with pipette solutions containing (in $\mathrm{mM}$ ): $155 \mathrm{KOH}, 5 \mathrm{KCl}$, 20 Hepes, 115 Mes, 10 BAPTA adjusted $\mathrm{pH}$ to 8.0 with $\mathrm{KOH}$. And the bath solution was $160 \mathrm{mM} \mathrm{KOH}, 10 \mathrm{mM}$ Hepes, $150 \mathrm{mM} \mathrm{Mes}$, and $2 \mathrm{mM} \mathrm{Ca(Mes)})_{2}$, adjusted to $\mathrm{pH}$ 7.4 with Mes. Solutions were applied directly via a local perfusion system allowing switching between different test solutions. Solution exchange time with this system is typically $<0.5 \mathrm{~s}$. Current waveforms were analyzed either with Clampfit or Grapher 8. All experiments were at room temperature $\left(\sim 22-25^{\circ} \mathrm{C}\right)$.

\section{Statistical analysis}

Statistical analysis was calculated using GraphPad Prism version 5.0 (GraphPad Software, San Diego, CA) or SPSS version 17.0. Results are given as mean \pm s.e.m. Comparisons were subjected to t-test (for two-group comparisons), one-way analysis of variance (for multigroup comparisons), or two-way analysis of variance with Bonferroni post hoc tests. Statistical significance was set at $\mathrm{p}<0.05$.

\section{Author contributions}

HCC, RD, KLF and XZ conceived and designed the experiments. RD, TW, YR, MKY, YC, YC, HC, XC, LM and $Y W$ performed the experiments and analyzed the data. $\mathrm{ZC}$ and $\mathrm{XZ}$ provided clinical samples. ZC gave intellectual advice. KLF, HCC and XZ wrote the paper. YR drew the working model.

\section{ACKNOWLEDGMENTS}

We thank Dr. Christopher Lingle from Washington University at St. Louis for his critical review and comments on the manuscript. This study was supported in part by grants from National Major Basic Research Program of China (2013CB967401, 2013CB967404), the National Natural Science Foundation of China (31230034 and 
31171116, 81571492, 81571390), the National Key Scientific Program of China (2015CB943003), RGC of Hong Kong (14120015, 14101114 and 461213), the Focused Investment Scheme of the Chinese University of Hong Kong and K.S. Lo Foundation (7104494). Guangdong Natural Science Foundation (2014A030313652 and 2014A030313785), Shenzhen Foundation of Science and Technology (GJHZ20140414170821192 and JCYJ20140414170821337), China Postdoctoral Science Foundation (2014M562224 and 2015T80926) and Clinical Doctor-Basic Scientist Combination Foundation of Shenzhen Second People's Hospital.

\section{CONFLICTS OF INTEREST}

The authors declared no conflicts of interest.

\section{REFERENCES}

1. Wassarman PM, Jovine L, Litscher ES. A profile of fertilization in mammals. Nat Cell Biol. 2001; 3: E59-64. https://doi.org/10.1038/35055178.

2. Ren D, Navarro B, Perez G, Jackson AC, Hsu S, Shi Q, Tilly JL, Clapham DE. A sperm ion channel required for sperm motility and male fertility. Nature. 2001; 413: 603-9. https://doi.org/10.1038/35098027.

3. Ren D, Xia J. Calcium signaling through CatSper channels in mammalian fertilization. Physiology (Bethesda). 2010; 25: 165-75. https://doi.org/10.1152/physiol.00049.2009.

4. Kirichok Y, Navarro B, Clapham DE. Whole-cell patchclamp measurements of spermatozoa reveal an alkalineactivated $\mathrm{Ca} 2+$ channel. Nature. 2006; 439: 737-40. https:// doi.org/10.1038/nature04417.

5. Diao R, Fok KL, Chen H, Yu MK, Duan Y, Chung CM, Li Z, Wu H, Zhang H, Ji Z, Zhen W, Ng CF, Gui Y, et al. Deficient human beta-defensin 1 underlies male infertility associated with poor sperm motility and genital tract infection. Sci Transl Med. 2014; 6: 249ra108. https://doi. org/10.1126/scitranslmed.3009071.

6. Qi H, Moran MM, Navarro B, Chong JA, Krapivinsky G, Krapivinsky L, Kirichok Y, Ramsey IS, Quill TA, Clapham DE. All four CatSper ion channel proteins are required for male fertility and sperm cell hyperactivated motility. Proc Natl Acad Sci U S A. 2007; 104: 1219-23. https://doi. org/10.1073/pnas.0610286104.

7. Lishko PV, Botchkina IL, Fedorenko A, Kirichok Y. Acid extrusion from human spermatozoa is mediated by flagellar voltage-gated proton channel. Cell. 2010; 140: 327-37. https://doi.org/10.1016/j.cell.2009.12.053.

8. Darszon A, Nishigaki T, Beltran C, Trevino CL. Calcium channels in the development, maturation, and function of spermatozoa. Physiol Rev. 2011; 91: 1305-55. https://doi. org/10.1152/physrev.00028.2010.

9. Chung JJ, Navarro B, Krapivinsky G, Krapivinsky L, Clapham DE. A novel gene required for male fertility and functional CATSPER channel formation in spermatozoa. Nat Commun. 2011; 2: 153. https://doi.org/10.1038/ ncomms 1153 .

10. Jin J, Jin N, Zheng H, Ro S, Tafolla D, Sanders KM, Yan W. Catsper3 and Catsper4 are essential for sperm hyperactivated motility and male fertility in the mouse. Biol Reprod. 2007; 77: 37-44. https://doi.org/10.1095/ biolreprod.107.060186.

11. Carlson AE, Quill TA, Westenbroek RE, Schuh SM, Hille B, Babcock DF. Identical phenotypes of CatSper1 and CatSper2 null sperm. J Biol Chem. 2005; 280: 32238-44. https://doi.org/10.1074/jbc.M501430200.

12. Lishko PV, Botchkina IL, Kirichok Y. Progesterone activates the principal $\mathrm{Ca} 2+$ channel of human sperm. Nature. 2011; 471: 387-91. https://doi.org/10.1038/nature09767.

13. Strunker T, Goodwin N, Brenker C, Kashikar ND, Weyand I, Seifert R, Kaupp UB. The CatSper channel mediates progesterone-induced $\mathrm{Ca} 2+$ influx in human sperm. Nature. 2011; 471: 382-6. https://doi.org/10.1038/nature09769.

14. Calogero AE, Burrello N, Barone N, Palermo I, Grasso U, D'Agata R. Effects of progesterone on sperm function: mechanisms of action. Hum Reprod. 2000; 15: 28-45.

15. Yin L, Chung CM, Huo R, Liu H, Zhou C, Xu W, Zhu H, Zhang J, Shi Q, Wong HY, Chen J, Lu Y, Bi Y, et al. A sperm GPI-anchored protein elicits sperm-cumulus cross-talk leading to the acrosome reaction. Cell Mol Life Sci. 2009; 66: 900-8. https://doi.org/10.1007/s00018-009-8482-2.

16. Miller MR, Mannowetz N, Iavarone AT, Safavi R, Gracheva EO, Smith JF, Hill RZ, Bautista DM, Kirichok Y, Lishko PV. Unconventional endocannabinoid signaling governs sperm activation via the sex hormone progesterone. Science. 2016; 352: 555-9. https://doi.org/10.1126/science. aad6887.

17. Mannowetz N, Miller MR, Lishko PV. Regulation of the sperm calcium channel CatSper by endogenous steroids and plant triterpenoids. Proc Natl Acad Sci U S A. 2017. https:// doi.org/10.1073/pnas.1700367114.

18. Brenker C, Goodwin N, Weyand I, Kashikar ND, Naruse M, Krahling M, Muller A, Kaupp UB, Strunker T. The CatSper channel: a polymodal chemosensor in human sperm. EMBO J. 2012; 31: 1654-65. https://doi.org/10.1038/ emboj.2012.30.

19. Yang D, Chertov O, Bykovskaia SN, Chen Q, Buffo MJ, Shogan J, Anderson M, Schroder JM, Wang JM, Howard OM, Oppenheim JJ. Beta-defensins: linking innate and adaptive immunity through dendritic and T cell CCR6. Science. 1999; 286: 525-8. https://doi.org/10.1126/ science. 286.5439.525.

20. Hoover DM, Boulegue C, Yang D, Oppenheim JJ, Tucker $\mathrm{K}, \mathrm{Lu} \mathrm{W}$, Lubkowski J. The structure of human macrophage inflammatory protein-3alpha /CCL20. Linking antimicrobial and $\mathrm{CC}$ chemokine receptor-6-binding activities with human beta-defensins. J Biol Chem. 2002; 277: 37647-54. https://doi.org/10.1074/jbc.M203907200. 
21. Caballero-Campo P, Buffone MG, Benencia F, ConejoGarcia JR, Rinaudo PF, Gerton GL. A role for the chemokine receptor CCR6 in mammalian sperm motility and chemotaxis. J Cell Physiol. 2014; 229: 68-78. https:// doi.org/10.1002/jcp.24418.

22. Xia J, Reigada D, Mitchell CH, Ren D. CATSPER channelmediated $\mathrm{Ca} 2+$ entry into mouse sperm triggers a tail-tohead propagation. Biol Reprod. 2007; 77: 551-9. https://doi. org/10.1095/biolreprod.107.061358.

23. Soderberg O, Gullberg $M$, Jarvius $M$, Ridderstrale $K$, Leuchowius KJ, Jarvius J, Wester K, Hydbring P, Bahram F, Larsson LG, Landegren U. Direct observation of individual endogenous protein complexes in situ by proximity ligation. Nat Methods. 2006; 3: 995-1000. https://doi.org/10.1038/nmeth947.

24. Skokowa J, Klimiankou M, Klimenkova O, Lan D, Gupta K, Hussein K, Carrizosa E, Kusnetsova I, Li Z, Sustmann C, Ganser A, Zeidler C, Kreipe $\mathrm{HH}$, et al. Interactions among HCLS1, HAX1 and LEF-1 proteins are essential for G-CSF-triggered granulopoiesis. Nat Med. 2012; 18: 15509. https://doi.org/10.1038/nm.2958.

25. Tamburrino L, Marchiani S, Vicini E, Muciaccia B, Cambi M, Pellegrini S, Forti G, Muratori M, Baldi E. Quantification of CatSper1 expression in human spermatozoa and relation to functional parameters. Hum Reprod. 2015. https://doi. org/10.1093/humrep/dev103.

26. Dacheux JL, Dacheux F. New insights into epididymal function in relation to sperm maturation. Reproduction. 2014; 147: R27-42. https://doi.org/10.1530/REP-13-0420.

27. Wettschureck N, Offermanns S. Mammalian G proteins and their cell type specific functions. Physiol Rev. 2005; 85: 1159-204. https://doi.org/10.1152/physrev.00003.2005.
28. Sun Y, McGarrigle D, Huang XY. When a G proteincoupled receptor does not couple to a $G$ protein. Mol Biosyst. 2007; 3: 849-54. https://doi.org/10.1039/b706343a.

29. Horne AW, Stock SJ, King AE. Innate immunity and disorders of the female reproductive tract. Reproduction. 2008; 135: 739-49. https://doi.org/10.1530/REP-07-0564.

30. Yarbrough VL, Winkle S, Herbst-Kralovetz MM. Antimicrobial peptides in the female reproductive tract: a critical component of the mucosal immune barrier with physiological and clinical implications. Hum Reprod Update. 2015; 21: 353-77. https://doi.org/10.1093/humupd/ dmu065.

31. Varona R, Villares R, Carramolino L, Goya I, Zaballos A, Gutierrez J, Torres M, Martinez AC, Marquez G. CCR6deficient mice have impaired leukocyte homeostasis and altered contact hypersensitivity and delayed-type hypersensitivity responses. J Clin Invest. 2001; 107: R3745. https://doi.org/10.1172/JCI11297.

32. Moser C, Weiner DJ, Lysenko E, Bals R, Weiser JN, Wilson JM. beta-Defensin 1 contributes to pulmonary innate immunity in mice. Infect Immun. 2002; 70: 3068-72. https://doi.org/10.1128/IAI.70.6.3068-3072.2002.

33. Organisation WH. WHO Laboratory Manual for the Examination and Processing of Human Semen, 5th ed. Geneva: World Health Organization. 2010.

34. Mortimer ST, Swan MA, Mortimer D. Effect of seminal plasma on capacitation and hyperactivation in human spermatozoa. Hum Reprod. 1998; 13: 2139-46. https://doi. org/10.1038/aja.2012.81. 